\title{
Original Article \\ Safety of Herbal Medicinal Products: Echinacea and Selected Alkylamides Do Not Induce CYP3A4 mRNA Expression
}

\author{
Maryam Modarai, ${ }^{1,2}$ Elisabete Silva, ${ }^{2}$ Andy Suter, ${ }^{3}$ Michael Heinrich, ${ }^{1}$ \\ and Andreas Kortenkamp ${ }^{2}$ \\ ${ }^{1}$ Centre for Pharmacognosy and Phytotherapy, The School of Pharmacy, University of London, 29/39 Brunswick Square, \\ London, WC1N 1AX, UK \\ ${ }^{2}$ Centre for Toxicology, The School of Pharmacy, University of London, 29/39 Brunswick Square, London, WC1N 1AX, UK \\ ${ }^{3}$ Bioforce AG, CH-9325 Roggwil, Switzerland
}

Correspondence should be addressed to Andreas Kortenkamp, andreas.kortenkamp@pharmacy.ac.uk

Received 20 May 2009; Accepted 2 October 2009

Copyright () 2011 Maryam Modarai et al. This is an open access article distributed under the Creative Commons Attribution License, which permits unrestricted use, distribution, and reproduction in any medium, provided the original work is properly cited.

\begin{abstract}
A major safety concern with the use of herbal medicinal products (HMP) is their interactions with conventional medicines, which are often mediated via the cytochrome P450 (CYP) system. Echinacea is a widely used over-the-counter HMP, with proven immunomodulatory properties. Its increasing use makes research into its safety an urgent concern. Previously, we showed that Echinacea extracts and its alkylamides (thought to be important for Echinacea's immunomodulatory activity) mildly inhibit the enzymatic activity of the main drug metabolising CYP isoforms, but to this date, there is insufficient work on its ability to alter CYP expression levels. We now report for the first time the effect of a commercial Echinacea extract (Echinaforce) and four Echinacea alkylamides on the transcription of the major drug metabolizing enzyme CYP3A4. HepG2 cells were exposed for 96 $\mathrm{h}$ to clinically relevant concentrations of Echinaforce $\left(22,11.6\right.$ and $1.16 \mu \mathrm{g} \mathrm{mL} \mathrm{L}^{-1}$ ) or the alkylamides (1.62 and $\left.44 \mathrm{nM}\right)$. CYP3A4 mRNA levels were quantified using real-time reverse transcription polymerase chain reaction (RT-PCR). Neither Echinaforce nor the alkylamides produced any significant changes in the steady-state CYP3A4 mRNA levels, under these conditions. In contrast, treatment with $50 \mu \mathrm{M}$ rifampicin resulted in a 3.8-fold up-regulation over the vehicle control. We conclude that Echinaforce is unlikely to affect CYP3A4 transcriptional levels, even at concentrations which can inhibit the enzymatic activity of CYP3A4. Overall, our data provides further evidence for the lack of interactions between Echinacea and conventional drugs.
\end{abstract}

\section{Introduction}

Interactions between herbal medicinal products (HMP) and conventional drugs are a major safety concern. One of the main pathways for such interactions is via the cytochrome P450 (CYP) enzymes. Direct inhibition or induction of CYP isoforms by HMP can alter the metabolism of conventional drugs, leading to adverse effects. An example showcasing the significance of such interactions is St. John's Wort, which has been shown to affect the pharmacokinetics of several important drugs [1], highlighting the need for in vitro investigations into the possible interactions of HMP with CYP isoforms [2].

Echinacea is a popular HMP, well known for its immunomodulatory properties and used worldwide for the treatment of upper respiratory tract infections [3-5]. Previously, we investigated in detail the ability of Echinacea to inhibit various CYP isoforms [6]. We showed that Echinacea and some of its alkylamides weakly inhibit a number of major CYP isoforms. We also screened 10 commercially available Echinacea liquid preparations (ELP) for CYP3A4 inhibitory activity and found that it varied considerably $\left(\mathrm{IC}_{50}\right.$ values 12.7-1817 $\mu \mathrm{g} \mathrm{mL}^{-1}$ ) [6].

Aside from direct enzymatic inhibition, HMPs can affect CYP activity by altering their transcriptional activity (i.e., induce or suppress CYP expression). Altering CYP expression will affect drug metabolism in three different ways. It can alter drug elimination, pro-drug activation, or drug bioactivation (i.e., conversion to toxic metabolites), all of which can have serious consequences $[7,8]$.

CYP gene induction may occur via the action of three intracellular receptors: the aryl hydrocarbon receptor (AhR), 
the constitutive androstane receptor (CAR) and the pregnane $\mathrm{X}$ receptor (PXR) $[7,8]$. PXR is believed to be the main mediator of CYP3A gene induction [7]. The mechanism of CYP induction is shown in Figure 1. An important example of CYP induction by HMP is St John's Wort (Hypericum perforatum), which has been shown to induce CYP3A4 through PXR activation and can significantly decrease the plasma concentration of concurrently used medicines (e.g., ciclosporin indinavir and the oral contraceptive) [9]. Other natural products, which can induce CYP expression, include kava kava (Piper methysticum G. Forster), used to treat anxiety and Qing hao (Artemisia ammua) used traditionally as an antipyretic [9].

To date, there is limited data on the induction of CYP enzymes by ELP. Hellum and colleagues [10] found that a commercial ELP (Echinagard-Madaus AG) moderately suppressed CYP3A4 expression in primary human hepatocytes. In addition, Gorski et al. [11] found that Echinacea could cause induction of CYP3A4 in intestinal cells, but suppressed hepatic CYP3A4 expression. Both authors directly assayed CYP activity alone, not the protein or mRNA steady-state levels and their results may be influenced by the presence of various Echinacea constituents that can inhibit CYP activity. Thus, the ability of Echinacea to induce CYP expression is still not well described and a more detailed characterization is needed.

We have carried out such an analysis of CYP3A4 induction in human hepatocellular carcinoma HepG2 cells by an ELP (Echinaforce), using real-time reverse transcription polymerase chain reaction (RT-PCR) to determine steady-state mRNA levels. In addition, since alkylamides are important both for the therapeutic activity of Echinacea [12] and its CYP inhibitory potency [13], we investigated whether the isolated alkylamides: dodeca$2 E, 4 E, 8 Z, 10 E / Z$-tetraenoic acid isobutylamide (i), dodeca$2 E, 4 E$-dienoic acid isobutylamide (ii), undeca- $2 E / Z$-ene8,10-diyonic acid isobutylamides (iii) and dodec-2-ene8,10-diyonic acid isobutylamide (iv) (Figure 2) can induce CYP3A4 transcription in the same system.

\section{Methods}

2.1. Chemicals. Hanks' balanced salt solution (HBSS), foetal bovine serum (FBS), minimal essential medium alpha with Glutamax-1 (MEM- $\alpha$ ) and hexamer random primers were all obtained from Invitrogen (Paisley, UK) Rifampicin HPLC grade, trypsin-EDTA, ethanol, thiazoyl blue tetrazolium bromide (MTT) cell culture tested, RNAse-DNAse free water, dimethylformamide, hydrochloric acid, glacial acetic acid and sodium dodecyl sulphate were purchased from Sigma-Aldrich Ltd (Poole, Dorset, UK). Moloney murine leukemia virus (M-MLV) reverse transcriptase and reverse transcriptase buffer, deoxynucleotide triphosphates (dNTP) and recombinant RNAsin ribonuclease inhibitor were obtained from Promega (Southampton, UK) iQ SYBR Green Supermix was purchased from BioRad Laboratories Inc. (Hertfordshire, UK) and Nucleopsin RNA II kit from Macherey-Nagel (Abgene, Epson, UK). Primers for $\beta$-actin, glyceraldehyde 3-phosphate dehydrogenase (GAPDH) and CYP3A4 were purchased as high quality, purified OliGold Primers from Eurogentec Ltd. (Hampshire, UK) (Table 1). The alkylamides dodeca-2E,4E,8Z,10E/Z-tetraenoic acid isobutylamide (1), dodeca- $2 E, 4 E$-dienoic acid isobutylamide (2), undeca-2E/Z-ene-8,10-diyonic acid isobutylamides (3) and dodec-2-ene-8,10-diyonic acid isobutylamide (4) were purchased from Phytolab GmbH and Co. KG, (Vestenbergsgreuth, Germany). Echinaforce (batch no: 018451) was a kind gift from Bioforce, Switzerland.

2.2. Cell Culture. HepG2 cells were a generous gift from Professor Ruth Duncan (Cardiff University, UK). HepG2 cells were routinely cultured in MEM- $\alpha$ supplemented with Glutamax and 10\% FBS, subcultured at $\sim 70 \%$ confluence and discarded after 10 passages. The cells were kept in a humidified $37^{\circ} \mathrm{C}$ incubator with $5 \% \mathrm{CO}_{2}$.

2.3. Cell Viability Assay. The thiazoyl blue tetrazolium bromide (MTT) assay was used to determine cell viability. The assay was performed based on the protocol described by Hansen et al. [14]. HepG2 cells were seeded at a density of 5000 cells per well in flat bottomed 96-well microtitre plates (NUNC, Fisher Scientific, Leicestershire, UK) in $100 \mu \mathrm{l}$ of medium and allowed to attach for $48 \mathrm{~h}$. The medium was then removed and replaced with fresh medium containing the test substance. The ethanol carried over from the extract or the alkylamide stock solutions was kept below $0.1 \%$ to prevent enzyme denaturation and cytotoxicity. 1:3 serial dilution series was made from working stock solutions of the Echinacea extract (Echinaforce) and the alkyalmides. For Echinaforce two different working solutions were prepared: 11.6 and $64 \mu \mathrm{g} \mathrm{mL}^{-1}$. The $11.6 \mu \mathrm{g} \mathrm{mL}^{-1}$ working solution was prepared by simply diluting neat Echinaforce with media. To prepare the $64 \mu \mathrm{g} \mathrm{mL}^{-1}$ working solution, while keeping the ethanol content below $0.1 \%$, Echinaforce was dried in a rotary evaporator, freeze dried, re-dissolved in ethanol to yield a concentration of $85.85 \mathrm{mg} \mathrm{mL}^{-1}$ and then diluted to $64 \mu \mathrm{g} \mathrm{mL}^{-1}$ with media. Alkylamide working solutions were prepared by diluting ethanolic stock solutions to $3 \mu \mathrm{M}$ with media, keeping ethanol concentration at $0.1 \%$. A solvent control containing just medium with $0.1 \%$ ethanol was also included. Fresh test substance-containing medium was added daily for 4 days. Then the medium was removed, prior to adding $100 \mu \mathrm{l}$ assay media and $20 \mu \mathrm{l}$ MTT solution ( $5 \mathrm{mg} \mathrm{mL}^{-1}$ in phosphate buffered saline). The plate was incubated at $37^{\circ} \mathrm{C}$ for $4 \mathrm{~h}$ before adding $150 \mu \mathrm{l}$ of solubilization solution (20\% SDS 40\% DMF, 2\% glacial acetic acid and $1 \% \mathrm{vol} / \mathrm{vol} \mathrm{HCl}$ in distilled water, $\mathrm{pH} 4.7$ ) and leaving the plate to develop overnight. Formazan production was quantified by determining the absorbance at a wavelength of $560 \mathrm{~nm}$ using a plate reader (Labsystems Multiscan, VWR International).

2.4. Cell Treatment for Induction Studies. 300000 cells were seeded in $25 \mathrm{~cm}^{2}$ tissue culture flasks and left to adhere for $24 \mathrm{~h}$. The medium was then replaced with fresh medium containing the test-substance (Echinaforce: 22, 11.6, 


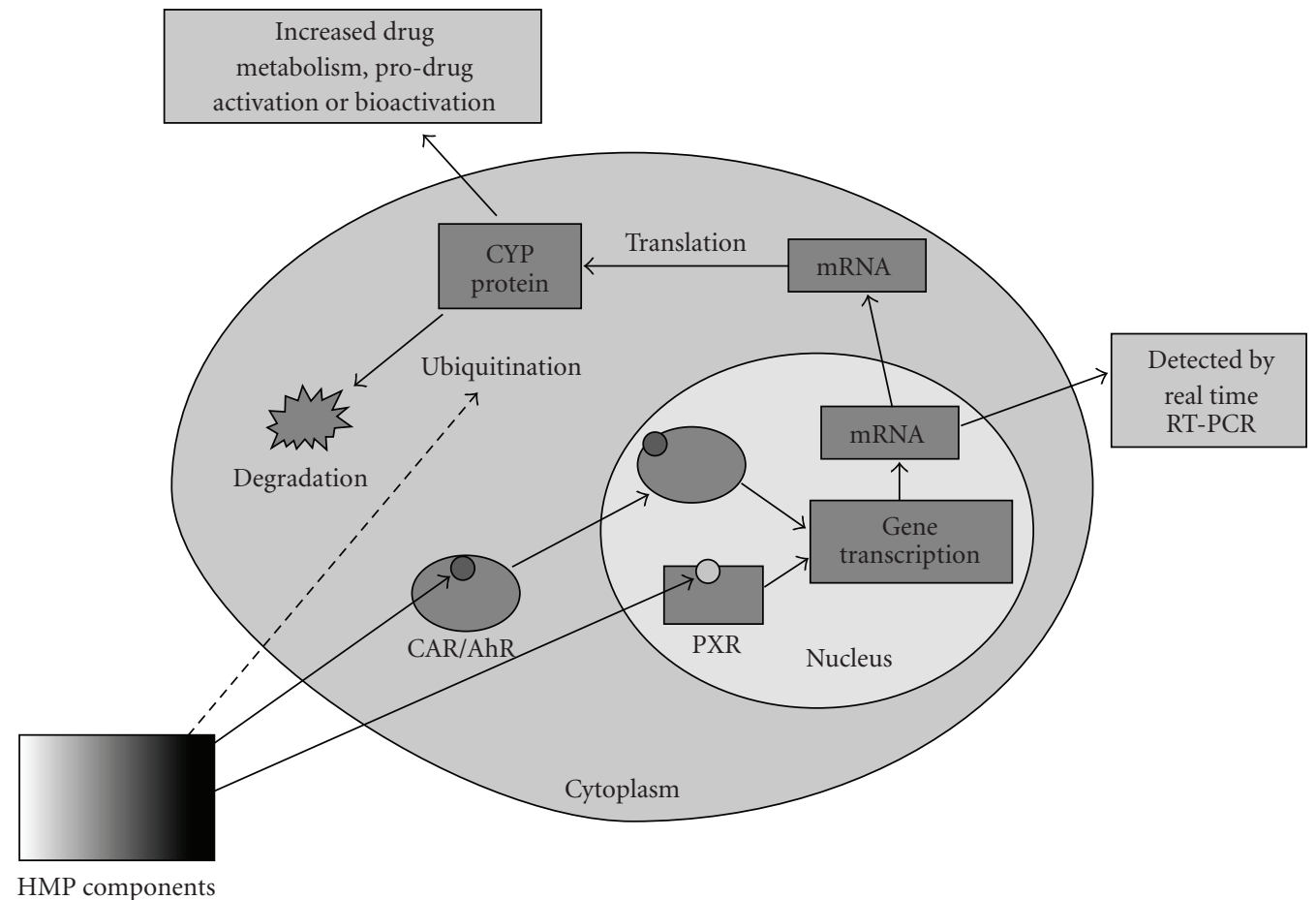

FIgURE 1: The control of CYP protein levels by HMP. Components of the HMP can either bind the AhR and CAR causing their translocation to the nucleus, or bind the inactive PXR in the nucleus and activate it. Following this binding step, AhR/CAR and PXR can initiate a sequence of events that increases CYP mRNA production and consequently increased CYP protein production. Increased CYP protein levels can accelerate drug metabolism, pro-drug activation and bioactivation. CYP3A4 transcription is mainly controlled by PXR. Increase in mRNA levels can be detected by quantification with real time RT-PCR. Another possibility is that HMP components may also affect post translational modifications such as ubiquitination, which results in protein degradation. This can lead to a change in CYP protein levels without affecting mRNA levels.<smiles>C/C=C/C=C/CC/C=C/C=C/C(=O)NCC(C)C</smiles>

(a)<smiles>C#CC#CCCCC/C=C/C(=O)NCC(C)C</smiles>

(c) (b)<smiles>CC#CC#CCCCC/C=C/C(=O)NCC(C)C</smiles>

(d)

FIgure 2: Structures of alkylamides assessed for CYP3A4 mRNA expression: (a) dodeca-2E, 4E,8Z, 10E/Z-tetraenoic acid isobutylamides (1), (b) dodeca-2E,4E-dienoic acid isobutylamide (2), (c) undeca-2E/Z-ene-8,10-diyonic acid isobutylamides (3) and (d) dodec-2-ene-8,10diyonic acid isobutylamide (4).

$1.16 \mu \mathrm{g} \mathrm{mL}{ }^{-1}$, alkylamides: $\left.1.62,44 \mathrm{nM}\right)$. Rifampicin at a concentration of $50 \mu \mathrm{M}$ was used as a positive control for CYP3A4 activation and the solvent control contained medium with $0.1 \%$ ethanol. The test substance containing medium was prepared by diluting neat Echinaforce, a stock solution of alkylamide, or a stock solution of rifampicin directly into the media ensuring that the concentration of ethanol did not exceed $0.1 \%$. Fresh test substance-containing medium was added daily for 4 days, before RNA isolation for real-time RT-PCR.

2.5. RNA Isolation. Cells were harvested using trypsinEDTA and total RNA was extracted using the Nucleospin RNA II kit, according to the manufacturer's instructions. The RNA was quantified spectrophotometrically by measuring absorbance (Abs) at $260 \mathrm{~nm}$ (NanoDrop ND $1000 \mathrm{UV}$ 
TABLE 1: $\beta$-actin, GAPDH and CYP3A4 primers.

\begin{tabular}{lcclcc}
\hline Gene & Gene accession no. & Primer & Sequence & Concentration (nM) & Product size \\
\hline \multirow{2}{*}{$\beta$-Actin } & \multirow{2}{*}{ X00351 } & Forward & $5^{\prime}$-TCAGCAAGCAGGAGTATG-3' & 300 & 300 \\
& & Reverse & $5^{\prime}$-GTCAAGAAAGGGTGTAACG-3' & 97 \\
GAPDH & \multirow{2}{*}{ NM_002046 } & Forward & $5^{\prime}$-TCTCTGCTCCTCCTGTTC-3' & 900 & 900 \\
& & Reverse & $5^{\prime}$-GCCCAATACGACCAAATCC-3' & 200 \\
CYP3A4 & \multirow{2}{*}{ NM_017460 } & Forward & $5^{\prime}$-ATCATTGCTGTCTCCAACCTTCAC-3' & 200 \\
& & Reverse & $5^{\prime}$-TGCTTCCCGCCTCAGATTTCTC-3' & 200 \\
\hline
\end{tabular}

Genebank accession numbers, primer sequences, concentrations and product sizes are shown all genes.

Spectrophotometer). The purity of the final preparations was determined by calculating the ratios Abs 260/280.

2.6. Reverse Transcription. For each sample, $2.5 \mu \mathrm{g}$ of total RNA was reverse transcribed using M-MLV Reverse Transcriptase according to the manufacturer's instructions. Briefly, RNA was diluted to $125 \mathrm{ng} \mathrm{mL}^{-1}$, then $7 \mu \mathrm{l}$ of $5 \times$ reaction buffer, $4 \mu \mathrm{l}$ dNTP ( $10 \mathrm{mM}$ each), $1 \mu \mathrm{l}$ RNase inhibitor and $1 \mu \mathrm{l}$ hexamer primers were added to $20 \mu \mathrm{l}$ of diluted RNA on ice. The mixture was heated at $65^{\circ} \mathrm{C}$ for $10 \mathrm{~min}$ and then snap-cooled on ice for $2 \mathrm{~min}$, prior to the addition of $2 \mu \mathrm{l}$ of reverse transcriptase (200 units $\left.\mu \mathrm{l}^{-1}\right)$. The reaction was carried out at $42^{\circ} \mathrm{C}$ for $90 \mathrm{~min}$. The cDNA was stored at $-80^{\circ} \mathrm{C}$ until further use.

2.7. Real-Time PCR. The sequences of the primers used for real-time PCR are shown in Table 1 along with the Genebank accession numbers of the cDNA sequences used for primer design. Primer selection was accomplished by using the Beacon designer 5.1 software suite (Premier Biosoft International, Palo Alto USA). The primer concentration was optimized to achieve 98-100\% amplification efficiency (data not shown).

Real-time PCR analysis was carried out using an iCycler iQ optical system multicolour real-time PCR detection system with the iCycler optical system software version 3.1 (Biorad Laboratories Inc). The samples were prepared by mixing $10 \mu \mathrm{M}$ of each primer, $25 \mu \mathrm{l} 2 \times$ iQ SYBR Green Supermix, $2 \mu \mathrm{l}$ of $1: 10$ diluted cDNA and the appropriate volume of nuclease-free water. Two $20 \mu \mathrm{l}$ aliquots were used for the amplification reaction. All reactions were run in duplicate. The hot start polymerase was activated by heating at $95^{\circ} \mathrm{C}$ for $3 \mathrm{~min}$. The cycling conditions were: $0.1 \mathrm{~min}$ at $95^{\circ} \mathrm{C}$ (melting) and $0.45 \mathrm{~min}$ at $55^{\circ} \mathrm{C}$ (annealing and extension). Threshold values $\left(C_{t}\right)$ were calculated automatically by the software.

The $C_{t}$ data was processed according to the method described by Pfaffl [15]. Briefly, the Pfaffl equation [15] was first used to calculate the relative gene expression ratio, that is, the change in target gene expression divided by the change in the reference gene expression.

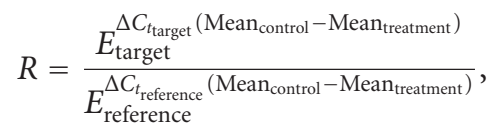

where $R$ is the relative gene expression ratio, $E$ is the amplification efficiency ( $E=2$ at $100 \%$ efficiency) and $\Delta C_{t}$ is the difference in threshold $\left(C_{t}\right)$ value.

Then the $R$ values were normalized with respect to the vehicle control. Statistical significance was determined using the relative expression software tool (REST), a randomization test developed by Pfaffl et al. [16].

\section{Results}

3.1. Determination of Clinically Relevant Concentration Ranges. Based on the results and predictions by other groups $[10,12,17]$, we determined that the clinically relevant Echinaforce concentration range lies between 1 and $25 \mu \mathrm{g} \mathrm{mL}-1$. For the alkylamides the clinically relevant concentrations were taken from Woelkart et al. [18, 19], who found that alkylamide (1) reached the highest plasma concentration of 44 or $1.62 \mathrm{nM}$ in human volunteers dosed with an $E$. angustifolia root extract and Echinaforce, respectively [18, 19].

3.2. Cell Viability Assay. The viability of HepG2 cells exposed to Echinaforce (up to $64 \mu \mathrm{g} \mathrm{mL}^{-1}$ ), ethanol (up to $0.1 \%$ ) or each of the alkylamides (up to $3 \mu \mathrm{M}$ ), for $96 \mathrm{~h}$ was investigated in the MTT assay. No loss of cell viability was observed.

3.3. Real-Time PCR Analysis. To determine if Echinaforce and its alkylamides can change the steady-state mRNA levels of CYP3A4, we exposed HepG2 cells to Echinaforce or alkylamides over a period of $96 \mathrm{~h}$. Rifampicin was used as the positive control and plain medium with $0.1 \%$ ethanol was used as the vehicle control. Following treatment, the mRNA was extracted and the levels of CYP3A4 mRNA were quantified by real time RT-PCR using $\beta$-actin as the internal control (reference gene). It has been reported that Echinaforce can up-regulate $\beta$-actin in human monocytes/macrophages [12]. Therefore, a second reference gene, GAPDH, was used to detect $\beta$-actin up-regulation. We found that exposure to Echinaforce (Figure 3 ) or the alkylamides (data not shown) did not result in up-regulation of $\beta$ actin expression in HepG2 cells, allowing $\beta$-actin to be used reliably as an internal control. Melt-curve analysis confirmed the absence of non-specific amplification products (data now shown). The results of the real time PCR analysis are shown in Figure 4 and Table 2. Exposure to rifampicin 


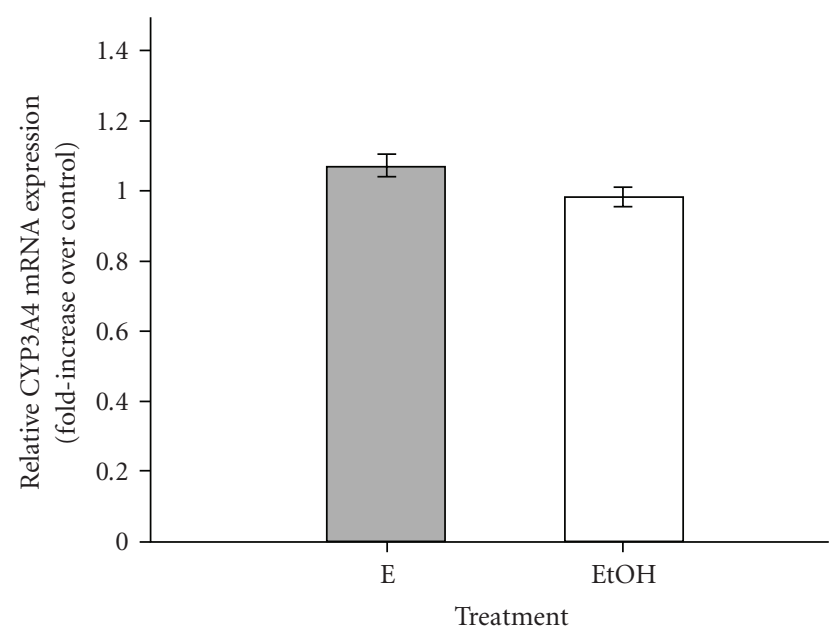

FIgURE 3: Relative CYP3A4 mRNA expression (fold increase over vehicle control) for $\beta$-actin using GAPDH as the reference gene, following treatment of HepG2 cells with Echinaforce (E: $22 \mu \mathrm{g} \mathrm{mL} \mathrm{m}^{-1}$ ) or with vehicle control $[0.1 \%$ ethanol $(\mathrm{EtOH})]$ for $96 \mathrm{~h}$. A value of 1 denotes no increase over the control. The values are the average of three independent experiments \pm SE.

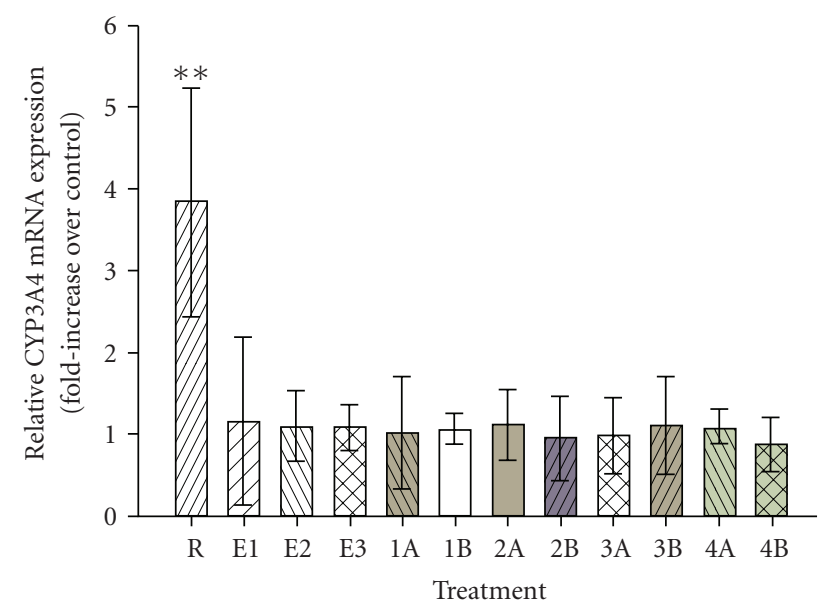

FIGURE 4: Relative CYP3A4 mRNA expression (fold increase over vehicle control) for CYP3A4 in HepG2 cells after a 96 h treatments with: $50 \mu \mathrm{M}$ rifampicin (R), Echinaforce (E1: $1.16 \mu \mathrm{g} \mathrm{m}^{-1}, \mathrm{E} 2$ : $11.6 \mu \mathrm{g} \mathrm{mL}^{-1}$, E3: $22 \mu \mathrm{g} \mathrm{mL}^{-1}$ ), alkylamide 1 (1A: $1.62 \mathrm{nM}, 1 \mathrm{~B}$ : $40 \mathrm{nM}$ ), alkylamide 2 (2A: $1.62 \mathrm{nM}, 2 \mathrm{~B}: 40 \mathrm{nM}$ ), alkylamide 3 (3A: $1.62 \mathrm{nM}, 3 \mathrm{~B}: 44 \mathrm{nM})$ and alkylamide 4 (4A: $1.62 \mathrm{nM}, 4 \mathrm{~B}: 44 \mathrm{nM})$. A value of 1 denotes no increase over the control. Values are the average of three independent experiments \pm SE. Statistically significant results $(P<.05$ with a randomization assay) are marked with $* *$.

resulted in a statistically significant $(P<.05)$ up-regulation of CYP3A4 expression (3.8-fold) compared to the vehicle control $(0.1 \%$ ethanol $)$ as shown in Table 2 . In contrast, exposure to Echinaforce or the alkylamides did not produce any statistically significant changes (at the $5 \%$ level) in the CYP3A4 mRNA levels (see Table 2).
TABLE 2: Induction of CYP3A4 gene expression in HepG2 cells by Echinaforce and its alkylamides.

\begin{tabular}{lccc}
\hline Treatment & Concentration & $\begin{array}{c}\text { Relative CYP3A4 } \\
\text { mRNA expression }\end{array}$ & $( \pm)$ SE \\
\hline Rifampicin & $50 \mu \mathrm{M}$ & 3.83 & 1.39 \\
Echinaforce & $1.16 \mu \mathrm{g} \mathrm{mL}^{-1}$ & 1.16 & 1.03 \\
& $11.6 \mu \mathrm{g} \mathrm{mL}^{-1}$ & 1.09 & 0.44 \\
Alkylamide 1 & $22 \mu \mathrm{gLL}^{-1}$ & 1.08 & 0.28 \\
& $1.62 \mathrm{nM}$ & 1.03 & 0.69 \\
Alkylamide 2 & $44 \mathrm{nM}$ & 1.07 & 0.19 \\
& $1.62 \mathrm{nM}$ & 1.11 & 0.44 \\
Alkylamide 3 & $1.62 \mathrm{nM}$ & 0.95 & 0.52 \\
& $44 \mathrm{nM}$ & 0.98 & 0.46 \\
Alkylamide 4 & $1.62 \mathrm{nM}$ & 1.11 & 0.60 \\
& $44 \mathrm{nM}$ & 1.08 & 0.22 \\
\hline
\end{tabular}

The cells were treated for $96 \mathrm{~h}$, changing the test substance containing medium every $24 \mathrm{~h}$. Values are the average of three independent experiments \pm SE.

${ }^{\mathrm{a}}$ Fold increase over the vehicle control.

\section{Discussion}

This is the first study to investigate the influence of an Echinacea preparation (Echinaforce) and four alkylamides on the steady state CYP3A4 mRNA level in HepG2 cells. No statistically significant changes in the mRNA steadystate level of CYP3A4 were observed after treating the cells with clinically relevant concentrations of Echinaforce or any of the alkylamides. In contrast, treatment with rifampicin resulted in a 3.8-fold up-regulation of CYP3A4. This value is in agreement with other studies with rifampicin [7, 20]. Therefore, we conclude that the compounds found in Echinaforce and the alkylamides tested have no effect on CYP3A4 transcriptional activity in HepG2 cells. It is possible that Echinaforce or the alkylamides might induce CYP3A4 expression at higher concentrations than the ones we tested. However, this would be at levels well above the clinically relevant range and, thus, would have no practical significance.

The effect of Echinaforce on the induction of other CYP enzymes has not been investigated and the apparent inability of Echinaforce to induce CYP3A4 does not imply that this will be the case for the remaining isoforms. However, due to the prominent role of CYP3A4 in drug metabolism any alteration of CYP3A4 activity is a major contributor to HMPdrug interactions.

It is important to note that we investigated mRNA steady-state levels instead of the actual CYP3A4 protein expression. Therefore, it is not possible to rule out that Echinaforce might affect the post-translational regulation of CYP3A4 expression (Figure 1). Several types of posttranslational regulation for CYPs have been documented including ubiquitination, nitration and phosphorylation [21]; however, we are not aware of published work suggesting that CYP post-translational regulation can be affected by HMPs. 
Hellum et al. [10] found that two other Echinacea preparations (Echinagard and Madaus AG) caused a small, but significant suppression of CYP3A4 activity in cultured primary human hepatocytes. This discrepancy could be the result of the differences in methodology. Hellum et al. [10] exposed the cells to much higher (4-80 times, i.g., 4.735-473.5 $\mu \mathrm{g} \mathrm{mL}^{-1}$ ) Echinacea purpurea concentrations, and assayed enzyme activity instead of determining mRNA levels. We have previously shown [6] that Echinacea preparations can directly inhibit CYP3A4. Hence, it is possible that the reduction in CYP3A4 activity observed [10] is not in fact related to reduced CYP3A4 expression, but rather a direct inhibitory effect on its enzyme activity. A time course study would have to be carried out to distinguish between reduced expression and direct enzyme inhibition.

Although without effect on CYP3A4 mRNA levels, the Echinacea extract (Echinaforce) concentrations tested here were sufficient to cause observable inhibition of CYP3A4 activity. The $\mathrm{IC}_{50}$ for CYP3A4 inhibition estimated for Echinacea [6] was $27.2 \mu \mathrm{g} \mathrm{mL}^{-1}$, close to the $22 \mu \mathrm{g} \mathrm{mL}^{-1}$ employed in the present CYP induction study.

HepG2 cells are a human hepatocarcinoma cell line and thus, they do not exactly mirror the CYP profile present in the human liver. However, the mechanism controlling CYP3A4 expression in HepG2 cells are identical to those of human hepatocytes and thus, if Echinaforce does not induce CYP3A4 in HepG2 cells it is highly likely that it will not do so in human hepatocytes either. Therefore, overall, our results suggest that CYP3A4 induction can presumably be excluded as an avenue for interactions between Echinaforce or its alkylamides (the major active constituents) and conventional medicines thus reducing the risk of adverse effects arising from such interactions. Overall, this data improves our understanding of the safety profile of Echinacea. It also shows that Echinacea extracts are unlikely to cause cytochrome P450 mediated interactions with conventional medicines [22]. This is in agreement with the phamacovigilance data, as there is a lack of reports documenting interactions between Echinacea and concurrently used medication.

\section{Funding}

Bioforce, Switzerland and the Maplethorpe Trust (University of London).

\section{Acknowledgment}

The authors are grateful to the Maplethorpe Trust for supporting M.M. with a postdoctoral fellowship.

\section{References}

[1] A. A. Izzo, "Herb-drug interactions: an overview of the clinical evidence," Fundamental and Clinical Pharmacology, vol. 19, no. 1, pp. 1-16, 2005.

[2] BfArM, September 2009, http://www.phytotherapy.org/Interaktionen.pdf.

[3] J. Barnes, L. A. Anderson, S. Gibbons, and J. D. Phillipson, "Echinacea species (Echinacea angustifolia (DC.) Hell.,
Echinacea pallida (Nutt.) Nutt., Echinacea purpurea (L.) Moench): a review of their chemistry, pharmacology and clinical properties," Journal of Pharmacy and Pharmacology, vol. 57, no. 8, pp. 929-954, 2005.

[4] P. S. Haddad, G. A. Azar, S. Groom, and M. Boivin, "Natural health products, modulation of immune function and prevention of chronic diseases," Evidence-Based Complementary and Alternative Medicine, vol. 2, no. 4, pp. 513-520, 2005.

[5] K. Takeda and K. Okumura, "CAM and NK cells," EvidenceBased Complementary and Alternative Medicine, vol. 1, pp. 1727, 2004.

[6] M. Modarai, J. Gertsch, A. Suter, M. Heinrich, and A. Kortenkamp, "Cytochrome P450 inhibitory action of Echinacea preparations differs widely and co-varies with alkylamide content," Journal of Pharmacy and Pharmacology, vol. 59, no. 4, pp. 567-573, 2007.

[7] N. J. Hewitt, E. L. Lecluyse, and S. S. Ferguson, "Induction of hepatic cytochrome P450 enzymes: methods, mechanisms, recommendations, and in vitro-in vivo correlations," Xenobiotica, vol. 37, no. 10-11, pp. 1196-1224, 2007.

[8] A. R. Khuda-Bukhsh, S. S. Battacharyya, S. Paul, S. Dutta, and B. P. Boujedaini, "Modulation of signal proteins: a plausible mechanism to explain how a potentized drug Secale Cor 30C diluted beyond Avogadro's limits combats skin papilloma in mice," Evidence-Based Complementary and Alternative Medicine, 2009.

[9] J. L. Staudinger, X. Ding, and K. Lichti, "Pregnane X receptor and natural products: beyond drug-drug interactions," Expert Opinion on Drug Metabolism and Toxicology, vol. 2, no. 6, pp. 847-857, 2006.

[10] B. H. Hellum, Z. Hu, and O. G. Nilsen, "The induction of CYP1A2, CYP2D6 and CYP3A4 by six trade herbal products in cultured primary human hepatocytes," Basic and Clinical Pharmacology and Toxicology, vol. 100, no. 1, pp. 23-30, 2007.

[11] J. C. Gorski, S.-M. Huang, A. Pinto et al., "The effect of echinacea (Echinacea purpurea root) on cytochrome P450 activity in vivo," Clinical Pharmacology and Therapeutics, vol. 75, no. 1, pp. 89-100, 2004.

[12] J. Gertsch, R. Schoop, U. Kuenzle, and A. Suter, "Echinacea alkylamides modulate TNF- $\alpha$ gene expression via cannabinoid receptor CB2 and multiple signal transduction pathways," FEBS Letters, vol. 577, no. 3, pp. 563-569, 2004.

[13] M. Modarai, M. Yang, A. Kortenkamp, and M. Heinrich, "Metabolomic profiling of liquid Echinacea medicinal products with in vitro inhibitory effects on cytochrome P450 3A4 (CYP3A4)," Planta Med, vol. 76, no. 4, pp. 378-385, 2010.

[14] M. B. Hansen, S. E. Nielsen, and K. Berg, "Re-examination and further development of a precise and rapid dye method for measuring cell growth/cell kill," Journal of Immunological Methods, vol. 119, no. 2, pp. 203-210, 1989.

[15] M. W. Pfaffl, "A new mathematical model for relative quantification in real-time RT-PCR," Nucleic Acids Research, vol. 29, no. 9 , p. e45, 2001.

[16] M. W. Pfaffl, G. W. Horgan, and L. Dempfle, "Relative expression software tool (REST) for group-wise comparison and statistical analysis of relative expression results in realtime PCR," Nucleic Acids Research, vol. 30, no. 9, p. e36, 2002.

[17] R. M. Brinkeborn, D. V. Shah, and F. H. Degenring,

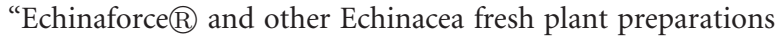
in the treatment of the common cold: a randomized, placebo controlled, double-blind clinical trial," Phytomedicine, vol. 6, no. 1, pp. 1-6, 1999.

[18] K. Woelkart, C. Koidl, A. Grisold et al., "Bioavailability and pharmacokinetics of alkamides from the roots of Echinacea 
angustifolia in humans," Journal of Clinical Pharmacology, vol. 45, no. 6, pp. 683-689, 2005.

[19] K. Woelkart, E. Marth, A. Suter et al., "Bioavailability and pharmacokinetics of Echinacea purpurea preparations and their interaction with the immune system," International Journal of Clinical Pharmacology and Therapeutics, vol. 44, no. 9, pp. 401-408, 2006.

[20] A. Sumida, S. Fukuen, I. Yamamoto, H. Matsuda, M. Naohara, and J. Azuma, "Quantitative analysis of constitutive and inducible CYPs mRNA expression in the HepG2 cell line using reverse transcription-competitive PCR," Biochemical and Biophysical Research Communications, vol. 267, no. 3, pp. 756-760, 2000.

[21] M. Aguiar, R. Masse, and B. F. Gibbs, "Regulation of cytochrome P450 by posttranslational modification," Drug Metabolism Reviews, vol. 37, no. 2, pp. 379-404, 2005.

[22] M. Heinrich, M. Modarai, and A. Kortenkamp, "Herbal extracts used for upper respiratory tract infections: are there clinically relevant interactions with the cytochrome $\mathrm{P} 450$ enzyme system?" Planta Medica, vol. 74, no. 6, pp. 657-660, 2008. 


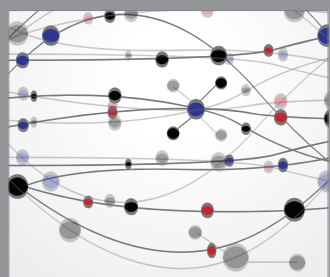

The Scientific World Journal
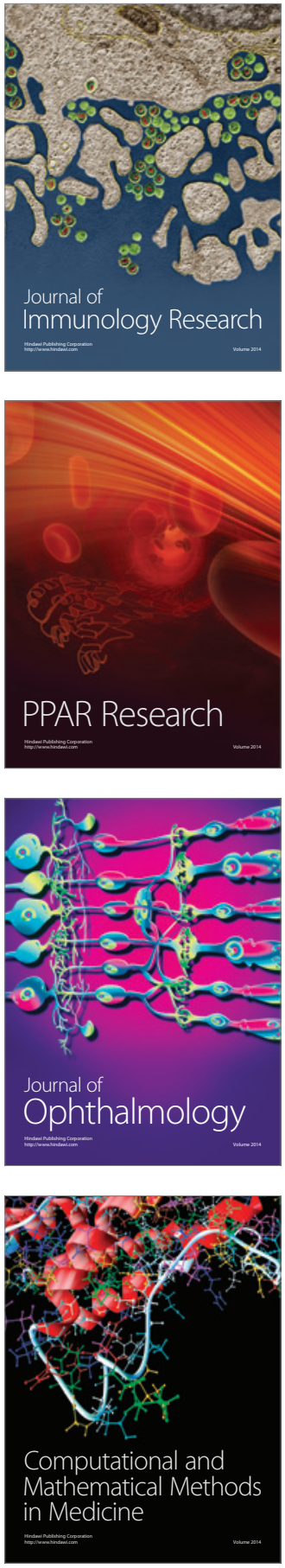

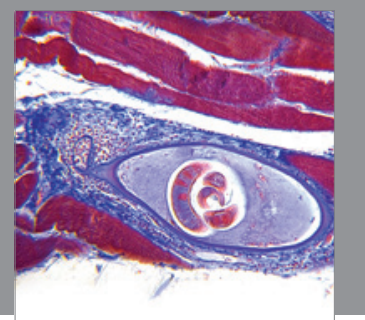

Gastroenterology

Research and Practice
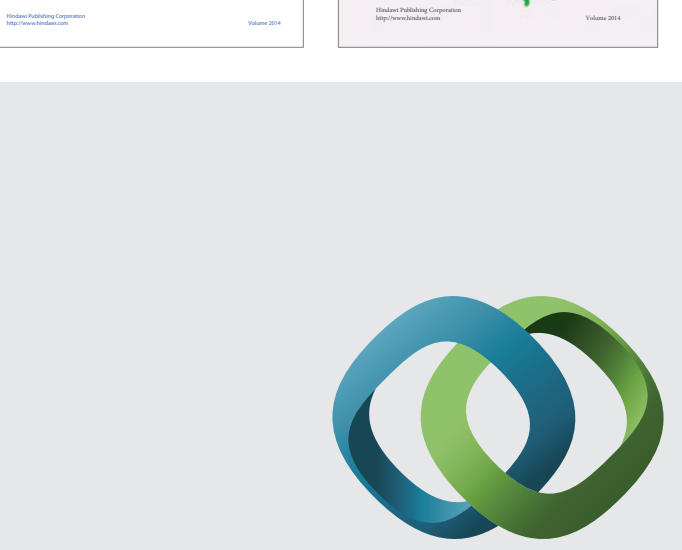

\section{Hindawi}

Submit your manuscripts at

http://www.hindawi.com
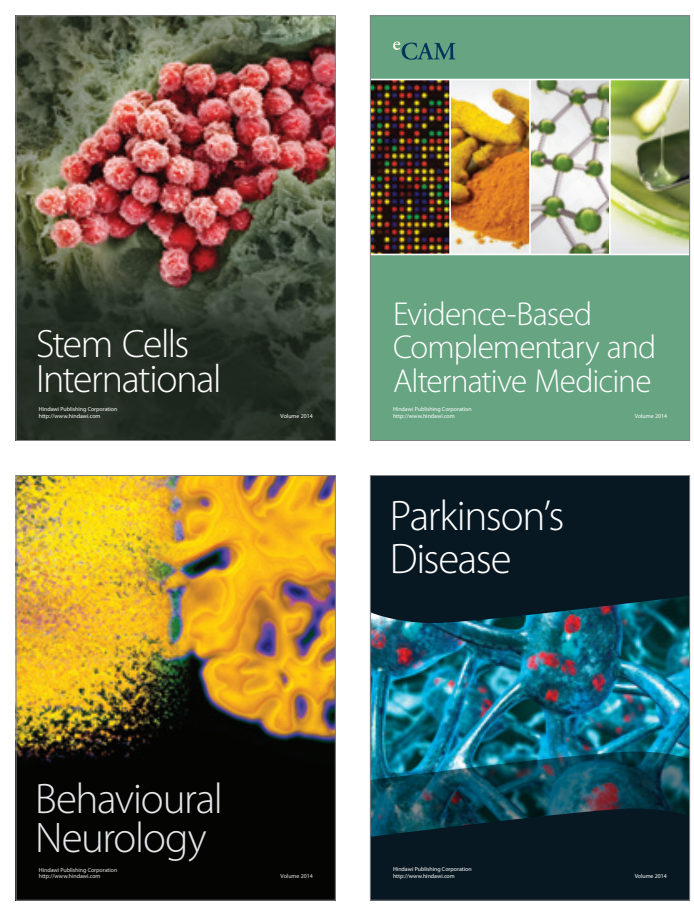

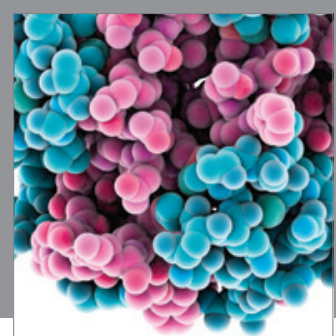

Journal of
Diabetes Research

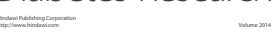

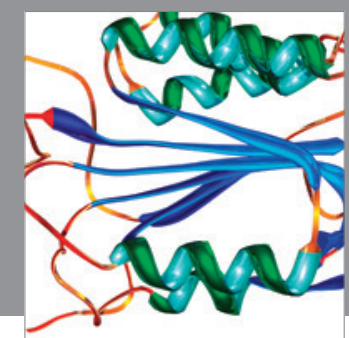

Disease Markers
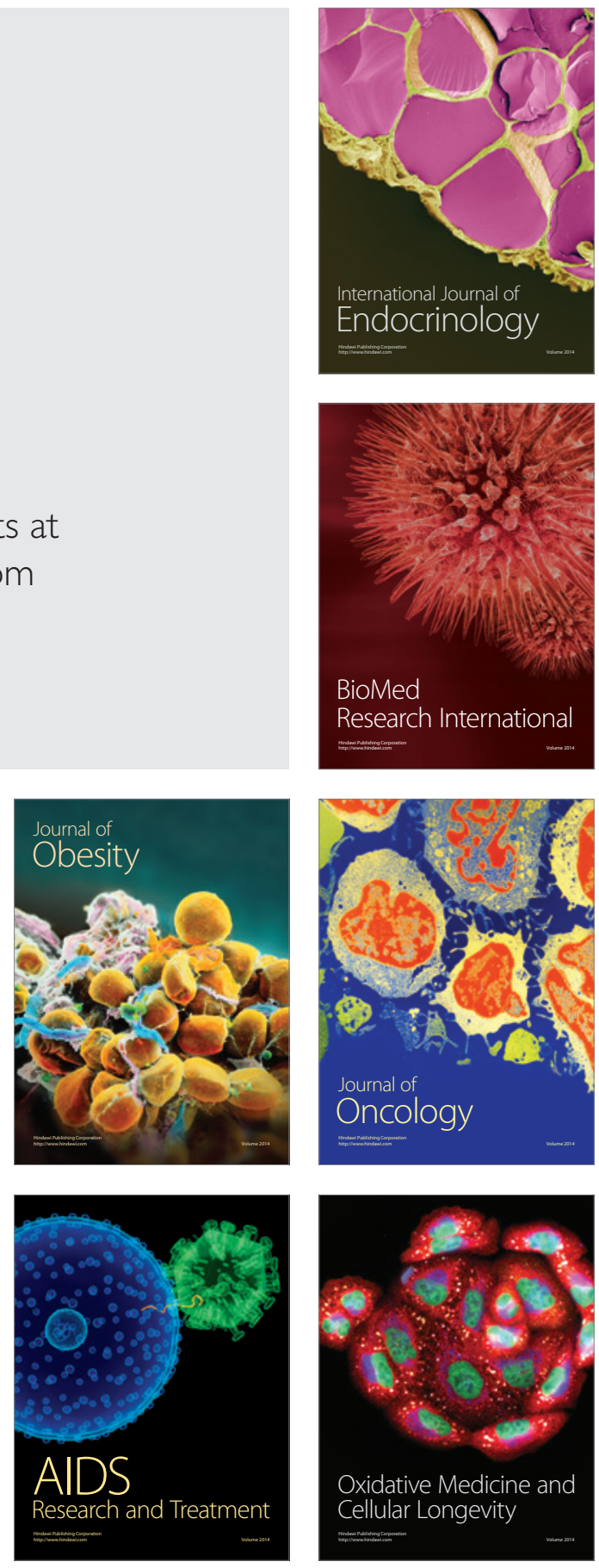